\title{
COMPARATIVE PERFORMANCE OF SCREEN AND SHEET CATHODES IN DECOLORIZATION OF ACID RED 14 BY ELECTROCOAGULATION
}

\author{
Olfat A.Fadali $^{(1)}$, Enass T.Said ${ }^{(1)}$, \\ Omnia H Abdelraheem ${ }^{(2)}$, Merfat H.Ahmed ${ }^{(1)}$, Nashwa Z. Mohamed ${ }^{(1)}$ \\ ${ }^{(1)}$ Chemical Engineering Department, Faculty of Engineering, Minia University, El-Minia, Egypt \\ ${ }^{\text {(2) }}$ Basic Engineering Sciences Department, Faculty of Engineering, Beni-Suef University, Egypt
}

\begin{abstract}
This study investigated the efficiency of decolorization of Acid Red 14 dye solution using screen cathode and compare the results with sheet cathode by electrocoagulation. A simple electrochemical cell was performed with horizontal mild steel iron disc anode and vertical stainless steel cylindrical cathodes (screen or sheet). Process duration, agitation speed, current density, initial dye concentration and electrolyte $\mathrm{NaCl}$ concentrations were the variables studied. It was found that screen cathode was more effective than sheet cathode. . For dye solution with $50 \mathrm{ppm}$ and agitation speed $100 \mathrm{rpm}$ after $18 \mathrm{~min}, 86 \%$ color removal was achieved on using screen cathode, while $77 \%$ color removal was achieved on using sheet cathode. The higher efficiency of screen cathode is attributed to the fact that screen acts as turbulence promoter and generate high turbulence intensity.
\end{abstract}

Key words: Screen cathode, Sheet cathode, Turbulence promoter, Electrical energy consumption.

\section{INTRODUCTION}

Electrocoagulation is a wastewater treatment process involving the generation of coagulants in situ by the dissolution of metal ions electrochemically from the anode with the simultaneous formation of hydroxyl ions and hydrogen gas at the cathode. The metal ions form flocculates which traps the contaminants while the hydrogen gas floats these particles (Gomes et al., 2009) (Chafi M et al., 2011).

This method is categorized by simple equipment and easy operation. Electrocoagulation process (EC) has attracted a great deal of attention for the treatment of the textile dye wastewater, purification of wastewater, tannery wastewater and domestic wastewater, also separation of crude oil from oil-in-water emulsions, suspended solids and even inorganic and organic pollutants that can be flocculated. (Kobya et al., 2017); (Bassyounia et al.2017); (El Ashtoukhy E-S and Amin N. K., 2010)

The effect of EC reactor design parameters on the treatment of wastewater has received a great deal of attention in the existing literature on the utilization of EC technology. Fadali, O.A. et al.,
(2016) evaluated different EC reactors to evaluate the factors that may affect the treatment of a wastewater obtained from Kuwait Gulf Oil Company. Aluminum was used as a sacrificial anode.

Electrodes were arranged at different configurations (horizontal, vertical and vertical anode with horizontal cathode) to select the optimal one. Experimental results indicate that the horizontal arrangement gave the best results, and the efficiency of oil separation increased with the increase of the treatment time, current density, anode diameter and concentration of electrolyte. However, it decreased with the increase of distance between electrodes.

Daneshvar, N. et al. (2004) studied the decolorization of Acid Red 14 and concluded that the experimental results showed that an EC cell with several electrodes was more effective than a simple electrochemical cell in color removal. The results also showed that within an EC cell, the series connection of the monopolar electrodes was more effective for the treatment process than the parallel connection in color removal. 
Fouad, Y. O. (2013) studied Separation of crude oil from oil-in-water emulsions in a square batch electrocoagulation cell, using an aluminum screen as the sacrificial anode and the cathode was a rectangular aluminum plate placed on the cell bottom below the anode. It was found that increasing the number of anodes per stack at the same current intensity, does not affect the efficiency of oil separation.

Demirci Y., et al., (2015) investigate the electrocoagulation for the treatment of a wastewater effluent taken from dying process of the industry. Aluminum electrodes were connected to an EC reactor in three different types: monopolar-parallel (MP-P), monopolarserial (MP-S), and bipolar-parallel (BP-P). The results show that all connection types show similar results in reducing color and turbidity, MP-P mode is the most cost effective for both electrode connection types. These results are in agreement with Kobya M et al., (2007) who studied the treatment of a textile wastewater by EC process. Two electrode materials, aluminum and iron were used. Both electrodes show similar results in reducing COD and turbidity. Nasrullaha M. et al., (2018) investigated the removal of chemical oxygen demand (COD), biochemical oxygen demand (BOD) and suspended solid (SS) from Palm Oil Mill Effluent by operating the electrochemical cell using various types of electrode design. The experiments were carried out by designing the electrode in vertical and horizontal orientation; monopolar series (MP-S), monopolar parallel (MP-P) and bipolar (BP) arrangement; and by applying aluminum, iron and steel wool as electrode material. The highest removal efficiency were obtained by selecting vertical orientation However, the economic study shows that MP-S arrangement has higher operating cost than MP-P and BP.

This work originally attempts to highlight the significance of electrode design including orientation by compare the effectiveness of two cylindrical vertical stainless steel cathodes (screen and sheet cathodes) versus horizontal mild steel disc anode in electrocoagulation reactor towards the decolorization of acidic dye from wastewater and to determine the different factors that may enhance the treatment process.

\section{EXPERIMENTAL WORK}

Fig. 1 shows schematic diagram of the experimental set up. It consists of a reactor and an electrical circuit. The reactor is a cylindrical glass container with $8 \mathrm{~cm}$ diameter and $13 \mathrm{~cm}$ height. The electrical circuit consists of DC power supply $(16 \mathrm{~V}, 20 \mathrm{~A})$, multi range voltameter connected in parallel and multi range ammeter connect in series. Two types of cathodes were used vertical cylindrical screen 40 mesh no. and cylindrical sheet both made from stainless steel and lining the reactor wall. The anode was a disc of mild steel with $5 \mathrm{~cm}$ diameter; the lower part was isolated with epoxy in horizontal position rests on reactor batten. The dye used was Acid Red 14 table. 1, a stock solution was prepared and the desired concentration was obtained by successive dilution with distilled water (concentration used ranging from 50 to $300 \mathrm{ppm}$ ), Different $\mathrm{NaCl}$ concentrations were used from 3 to $10 \mathrm{~g} / \mathrm{L}$. The current density applied in range between 60 to $250 \mathrm{~A} / \mathrm{m}^{2}$. Mixer used was a turbine type and stirring rate was ranged between 0 to $300 \mathrm{rpm}$, concentration of remaining dye after different time period was analyzed using spectrophotometer (Shimadzu Model Uv 1601) at wave length $515 \mathrm{~nm}$.

Table 1: Chemical structure and characteristics of Acid Red 14

\begin{tabular}{|c|c|c|c|c|}
\hline Chemical structure & $\begin{array}{c}\text { Color index } \\
\text { Number }\end{array}$ & $\begin{array}{c}\Lambda_{\text {max }} \\
\text { (nm) }\end{array}$ & $\begin{array}{c}\text { Chemical } \\
\text { class }\end{array}$ & $\begin{array}{c}\text { MW } \\
\text { (gmol }^{-1} \text { ) }\end{array}$ \\
\hline
\end{tabular}




\section{Results and Discussion}

Mechanism of electrochemical process include: oxidation and reduction reactions in synthetic waste water, dissolution of metallic anode and discharge the coagulant colloidal particles. During electrolysis the following reactions take place in the cell:

$2 \mathrm{H}_{2} \mathrm{O}+2 \mathrm{e}^{-}$

$2 \mathrm{OH}^{-}+\mathrm{H}_{2}$

(1)

With iron sheet as consumable electrode, ferrous $\left(\mathrm{Fe}^{+2}\right)$ and ferric $\left(\mathrm{Fe}^{+3}\right)$ are produced on the anode:

$\mathrm{Fe}$

(2)

$$
\mathrm{Fe}^{+2}+2 \mathrm{e}^{-}
$$

The dissolved ferrous ions at the anode undergo oxidation by dissolved oxygen to ferric ions, then hydrolyzed to ferric hydroxide. The ferric hydroxide particles are gelatinous and adsorb the dye on its surface and remove it from the solution by the cathodically evolved hydrogen floats ferric hydroxide particles along with the adsorbed dye to the solution surface and can be skimmed out.

\subsection{Effect of electrocoagulation time:}

The relation between percentages of color removal against electrocoagulation time shown for both vertical cylindrical screen and sheet cathodes represented in Fig. $2 \& 3$ respectively. At different agitation speed. It is obvious that color removal increases gradually with time, which may be attributed to many mechanisms may contribute to the color removal (Chen et al., 2000). Table. 2 shows removal efficiency obtained at 15 and 21 min by using vertical cylindrical screen cathode, where the efficiency reaches to $75.5 \%$ at $100 \mathrm{rpm}$ after $21 \mathrm{~min}$.

Table 2: Dye removal percent vs. rotational speed at different time using vertical cylindrical screen cathode $\left[\mathrm{C}_{0}=250\right.$

\begin{tabular}{|c|c|c|}
\multicolumn{2}{|c|}{ ppm, C.D $\left.=125 \mathrm{~A} / \mathrm{m}^{2}, \mathrm{C}_{\mathrm{NaCl}}=3 \mathrm{~g} / \mathrm{l}\right]$} \\
\hline $\begin{array}{c}\text { Rotational speed } \\
(\mathrm{rpm})\end{array}$ & $\begin{array}{c}\text { Color removal } \% \\
\text { at } 15 \mathrm{~min}\end{array}$ & $\begin{array}{c}\text { Color removal } \% \\
\text { at } 21 \mathrm{~min}\end{array}$ \\
\hline 0 & 31.23 & 48.85 \\
\hline 25 & 37.43 & 57.68 \\
\hline 50 & 43.49 & 62.58 \\
\hline 75 & 47.95 & 69.08 \\
\hline 100 & 53.47 & 75.59 \\
\hline 200 & 47.25 & 68.6 \\
\hline 300 & 41.89 & 62.02 \\
\hline
\end{tabular}

\subsection{Effect of impeller speed:}

Table 2 depicts the effect of agitation speed on color removal percentages. It can be seen that rotational speeds up to $100 \mathrm{rpm}$ improve the mixing efficiency between gelatinous ferric hydroxide and the dye with a consequent increase in the rate of color removal. On the other hand impeller speeds higher than $100 \mathrm{rpm}$ redisperse the dye again in the solution due to break down of the hydroxyl flocs with a consequent decrease in the percentage of dye removal. This result agrees with the finding of El-Shazly (2013). Based on the above results, an optimum $100 \mathrm{rpm}$ was selected for further experiments. Table 3 depeats effect of agitation speed on electrical energy consumption using the following equation:
Energy consumption (KWh/Kg dye removal) $=\frac{\text { Vcell.I.t }}{(\text { Co-Ct }) V}$

Where $V_{\text {cell }}=$ the cell voltage in vollts, $I=$ the applied electric current in amperes, $t=$ the electrolysis duration in hours, $\mathrm{C}_{0}=$ the initial dye concentration $(\mathrm{mg} / \mathrm{L}), \mathrm{C}_{\mathrm{t}}=$ the concentration at any time $\mathrm{t}(\mathrm{mg} / \mathrm{L})$ and $\mathrm{V}$ is the treated volume of dye solution in liters. Data in Table. 3 prove that the energy consumption decreases with increasing agitation speed and then increased after $100 \mathrm{rpm}$. This may attributed to, on increasing stirring energy consumption is reduced via reducing the cell voltage due to release gas bubbles adhering to the electrodes surface and decrease cell resistance (Yeager et at 1983) Besides, stirring reduce concentration polarization at the anode surface. 
Table 3: Effect of rotational speed on the color removal efficiency and energy consumption using screen vertical cylindrical cathode $\left[\mathrm{C}_{0}=250 \mathrm{ppm}, \mathrm{C} . \mathrm{D}=125 \mathrm{~A} / \mathrm{m}^{2}, \mathrm{C}_{\mathrm{NaCl}}=3 \mathrm{~g} / \mathrm{l}\right.$, time $\left.=21 \mathrm{~min}\right]$

\begin{tabular}{|c|c|c|}
\hline $\begin{array}{c}\text { Rotational speed } \\
(\mathrm{rpm})\end{array}$ & $\begin{array}{c}\text { Color removal } \\
\%\end{array}$ & $\begin{array}{c}\text { Energy consumption } \\
\left(\mathrm{KWh} / \mathrm{Kg}_{\text {dye removal }}\right)\end{array}$ \\
\hline 0 & 48.85 & 2.193 \\
\hline 25 & 57.68 & 1.872 \\
\hline 50 & 62.58 & 1.84 \\
\hline 75 & 69.08 & 1.799 \\
\hline 100 & 75.59 & 1.602 \\
\hline 200 & 68.6 & 1.643 \\
\hline 300 & 62.02 & 1.922 \\
\hline
\end{tabular}

\subsection{Effect of electrolyte concentration:}

Table 4 and Fig 4 shows effect of $\mathrm{NaCl}$ on both $\%$ color removal and energy consumption. It is cleary seen from data that $\%$ color removal increases with $\mathrm{NaCl}$ concentration while energy consumption decreases. The increase in the $\%$ of color removal may be the attributed to the ability of $\mathrm{Cl}^{-}$ions to destroy the passive iron oxide film formed on iron anode during electrolysis thus sustaining the formation of ferrous and ferric ions. The decrease in energy consumption is due to increase the conductivity and thus decreases electrical resistance.

Table 4: Effect of initial $\mathrm{NaCl}$ concentration on the color removal efficiency and energy consumption, using screen cathode, $\left[\mathrm{C}_{0}=250 \mathrm{ppm}, \mathrm{C} . \mathrm{D}=125 \mathrm{~A} / \mathrm{m}^{2}\right.$, rotational speed $=100 \mathrm{rpm}$, time $\left.=21 \mathrm{~min}\right]$

\begin{tabular}{|c|c|c|}
\hline $\begin{array}{c}\text { Conc. Of } \\
\mathbf{N a C l}\end{array}$ & $\begin{array}{c}\text { Color removal \% at } \\
\mathbf{2 1} \text { min }\end{array}$ & $\begin{array}{c}\text { Energy consumption at 21 } \\
\text { min }\end{array}$ \\
\hline 3 & 75.59 & 1.602 \\
\hline 5 & 78 & 1.397 \\
\hline 7 & 82.02 & 1.135 \\
\hline 10 & 86 & 0.666 \\
\hline
\end{tabular}

\subsection{Effect of Current Density:}

Table 5 depicts the effect of current density on color removal efficiency and energy consumption. An increase current density from 60 to $250 \mathrm{~A} / \mathrm{m}^{2}$, yields an increase in $\%$ color removal from 73.5 to $94.5 \%$. This is attributed that as current density increases, the rate of iron dissolution increases according to Faraday's law and in consequent more coagulants are produced in solution. Besides, production rate of hydrogen gas bubbles increase with a consequent increase in the flotation of ferric hydroxide gel which adsorb dye molecule on the surface (Arslan et al, 2008).

Table 5: Effect of current density on the color removal efficiency and energy consumption using screen cathode $\left[\mathrm{C}_{0}\right.$ $=250 \mathrm{ppm}, \mathrm{C}_{\mathrm{NaCl}}=10 \mathrm{~g} / \mathrm{l}$, rotational speed $=100 \mathrm{rpm}$, time $\left.=21 \mathrm{~min}\right]$

\begin{tabular}{|c|c|c|}
\hline $\begin{array}{c}\text { Current density } \\
\mathrm{A} / \mathrm{m}^{2}\end{array}$ & $\begin{array}{c}\text { Color removal } \\
\%\end{array}$ & $\begin{array}{c}\text { energy consumption } \\
\left(\mathrm{KWh} / \mathrm{Kg}_{\text {dye removal }}\right)\end{array}$ \\
\hline 60 & 73.53 & 0.356 \\
\hline 90 & 79.67 & 0.5 \\
\hline 125 & 86 & 0.666 \\
\hline 155 & 90.15 & 0.975 \\
\hline 200 & 92.81 & 1.551 \\
\hline 250 & 95.59 & 2.158 \\
\hline
\end{tabular}




\subsection{Effect of Initial dye concentration:}

Table 6 Fig 5 shows effect of dye concentration on $\%$ color removal and energy consumption. Data shows that both \% color removal and energy consumption decreased with increase initial dye concentration this is attributed to that, under a given set of conditions the efficiency of dye removal decreases with increasing dye concentration because ferric hydroxide flocs become saturated with adsorbed dye molecule and reach equilibrium state. Moreover, at high dye concentration, dye molecules tend to associate forming large aggregates of low diffusion coefficient, this retard the mixing process and the \% color removal. At the same time increase the initial dye concentration may passivates the anode due to increasing the amount of dye molecule adsorbed onto the anode surface, a similar phenomenon have been reported by El-Shazly et al., (2013).

Table 6: Effect of initial dye concentration on the color removal efficiency and energy consumption, using screen cathode, $\left[\mathrm{C}_{\mathrm{NaCl}}=10 \mathrm{~g} / \mathrm{l}, \mathrm{C} . \mathrm{D}=250 \mathrm{~A} / \mathrm{m}^{2}\right.$, rotational speed $=100 \mathrm{rpm}$, time $\left.=21 \mathrm{~min}\right]$

\begin{tabular}{|c|c|c|}
\hline $\begin{array}{c}\text { Intial Conc. } \\
\text { Of dye }\end{array}$ & $\begin{array}{c}\text { Color removal \% } \\
\text { at 21 min }\end{array}$ & $\begin{array}{c}\text { energy consumption at } \\
\text { 21 min }\end{array}$ \\
\hline 50 & 97.94 & 16.065 \\
\hline 150 & 96.2 & 5.546 \\
\hline 200 & 96.77 & 3.468 \\
\hline 250 & 95.59 & 2.158 \\
\hline 300 & 91.69 & 1.502 \\
\hline
\end{tabular}

improvement efficiency of color removal

\subsection{Comparative performance of screen} and sheet cathodes:

The study extended to compare \% color removal using screen cathode and sheet cathode, Fig 6. For dye solution with $50 \mathrm{ppm}$ and agitation speed $100 \mathrm{rpm}$ after $18 \mathrm{~min}, 86 \%$ color removal was achieved on using screen cathode, while 77 $\%$ color removal was achieved on using sheet cathode, The improvement in efficiency on using screen cathode may be attributed to the turbulence created by screen. The screen is acted as turbulence promoter when dye solution flows from tip of the impeller through screen opening as a Jet, creating high turbulence, this phenomena does not exist in case of sheet cathode.

\section{CONCLUSION}

* Increase current density, $\mathrm{NaCl}$ concentration and RPM increased \% color removal, while increase of dye concentration decreased $\%$ color removal.

* Screen cathode enhances the dye removal compared to sheet cathode. The is due to increase of turbulence intensity and in consequent increase of diffusion of dye molecules to be adsorbed on

iron hydroxide flocs and remove dye from solution.

\section{REFERENCES}

- Arslan A.I, Kabdash I., Hanbaba D,Kuybu E. "Electrocoagulation of real reactive dye bath effluent using aluminuim and stainless steel electrodes " Journal of Hazardous materials, 180, 66-173 (2008)

- Bassyounia D.G., Hamada H.A., ElAshtoukhy E-S.Z., Amin N.K, and Abd El-Latif M.M., Comparative performance of anodic oxidation and electrocoagulationas clean processes for electrocatalytic degradation of diazo dye AcidBrown 14 in aqueous medium, Journal of Hazardous Materials 335 178187(2017).

- Chafi M., Gourich B, Essadki A.H., Vial C., Fabregat A., Comparison of 
electrocoagulation using iron and aluminium electrodes with chemical coagulation for the removal of a highly soluble acid dye, Desalination 281285 292 (2011).

- Chenx. G, Chenc. X, Yue P.L, "Electrocoagulation and electroflotation of restaurant waste water" Journal of Environmental Engineering, 126, 858863(2000).

- Daneshvar N, Sorkhabi HA, Kasiri MBJ, Decolorization of dye solution containing Acid Red 14 by electrocoagulation with a comparative investigation of different electrode connections ,Hazard Mater. 2004 Aug 9;112(1-2):55-62

- Demirci Y., Lutfiye C. Pekel, Alpbaz Mustafa, Investigation of Different Electrode Connections in Electrocoagulation of Textile Wastewater Treatment Int. J. Electrochem. Sci., 10 2685 - 2693(2015)

- El Ashtoukhy E-S Z., Amin N K , Removal of acid green dye 50 from wastewater by anodic oxidation and electrocoagulation-A comparative study , Journal of hazardous materials 179(13):113-9, 2010.

- El-Shazly A.H., Daous M.A. "Investigations and Kinetics Study for the Effect of Solution Flow Rate on the Performance of Electrocoagulation Unit Used for Nutrients Removal", Int. J. Electrochem. Sci., 8, 12509 12518(2013).

- Fadali O.A., Ebrahiem E.E., El-Gamil A. and Hossam Altaher, Investigation of the Electrocoagulation Treatment Technique for the Separation of Oil from Wastewater, Journal of Environmental Science and Technology 9 (1): 62-74, 2016

- Gomes, J., Cocke D., Das, K. Guttula M., Tran D. and Beckman J., 2009.

Treatment of produced water by electrocoagulation. Proceedings of the TMS Annual Meeting and Exhibition,
February 15-19, San Francisco, CA. 459466 (2009).

- Kobya M., Bayramoglu M., Eyvaz M., Techno-economical evaluation of electrocoagulation for the textile wastewater using different electrode connections. J. Hazard. Mater. 148 311318 (2007).

- Nasrullaha M., Singh L., Krishnana S., Sakinaha M..Zularisam ,A.W, Electrode design for electrochemical cell to treat palm oil mill effluent by electrocoagulation process, Environmental Technology \& Innovation Volume 9, February, Pages 323341(2018).

- Yasmine Fouad, Electrocoagulation of Crude Oil From Oil-In-Water Emulsions Using a Rectangular Cell with a Horizontal Aluminium Wire Gauze Anode, journal of Dispersion Science and Technology, 34:214-221, (2013).

- Yeager E., Bockris J. O'M., Conway B., Sarangapani E. S., (Eds.): Electrodics: Transport, Vol. 6 aus: Comprehensive Treatise of Electrochemistry, Plenum Press, New York and Londo..(1983) 


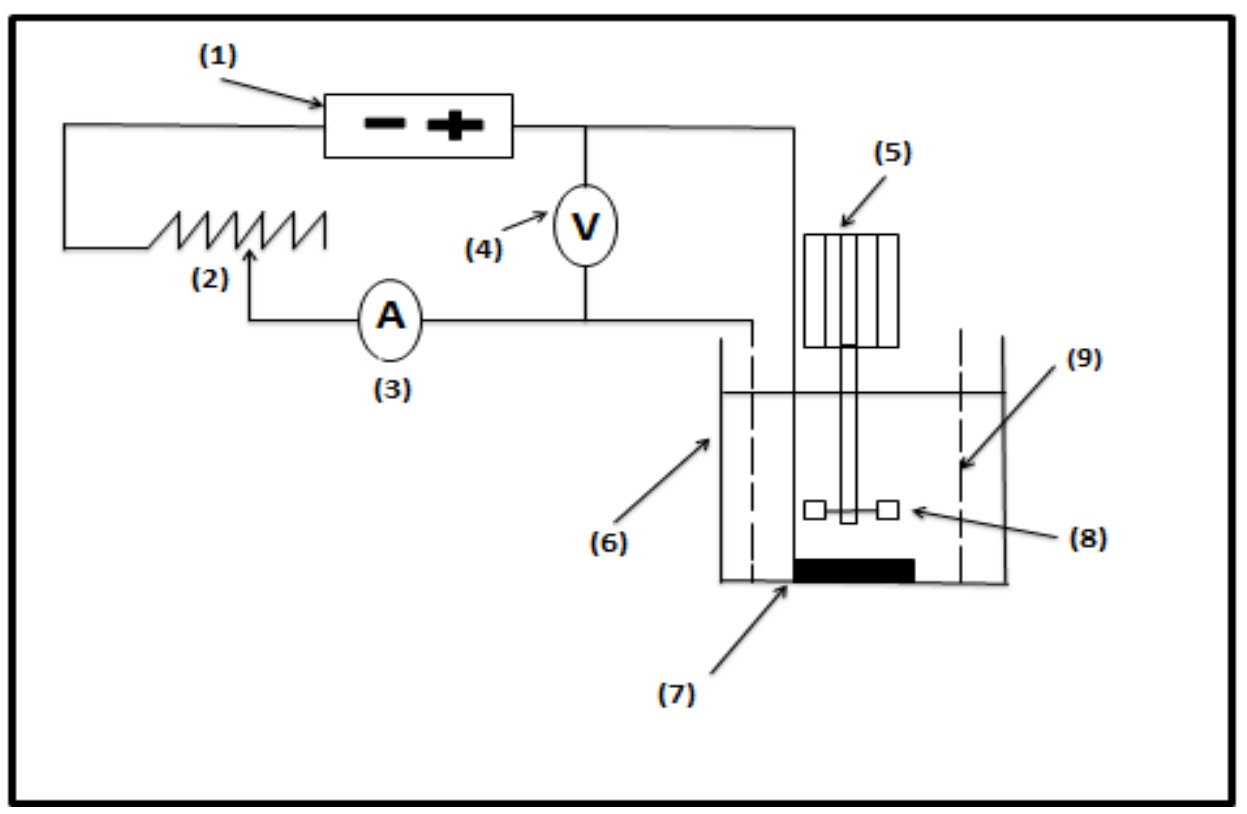

Fig. 1: Experimental set up of Batch EC reactor with screen cathode (1)DC Power supply , (2) Variable resistance , (3) Ammeter , (4) Voltameter، (5)Variable speed motor, (6) Glass vessel, (7) Mild steel disc anode، (8) Impeller, (9) St.st. cylindrical screen cathode.

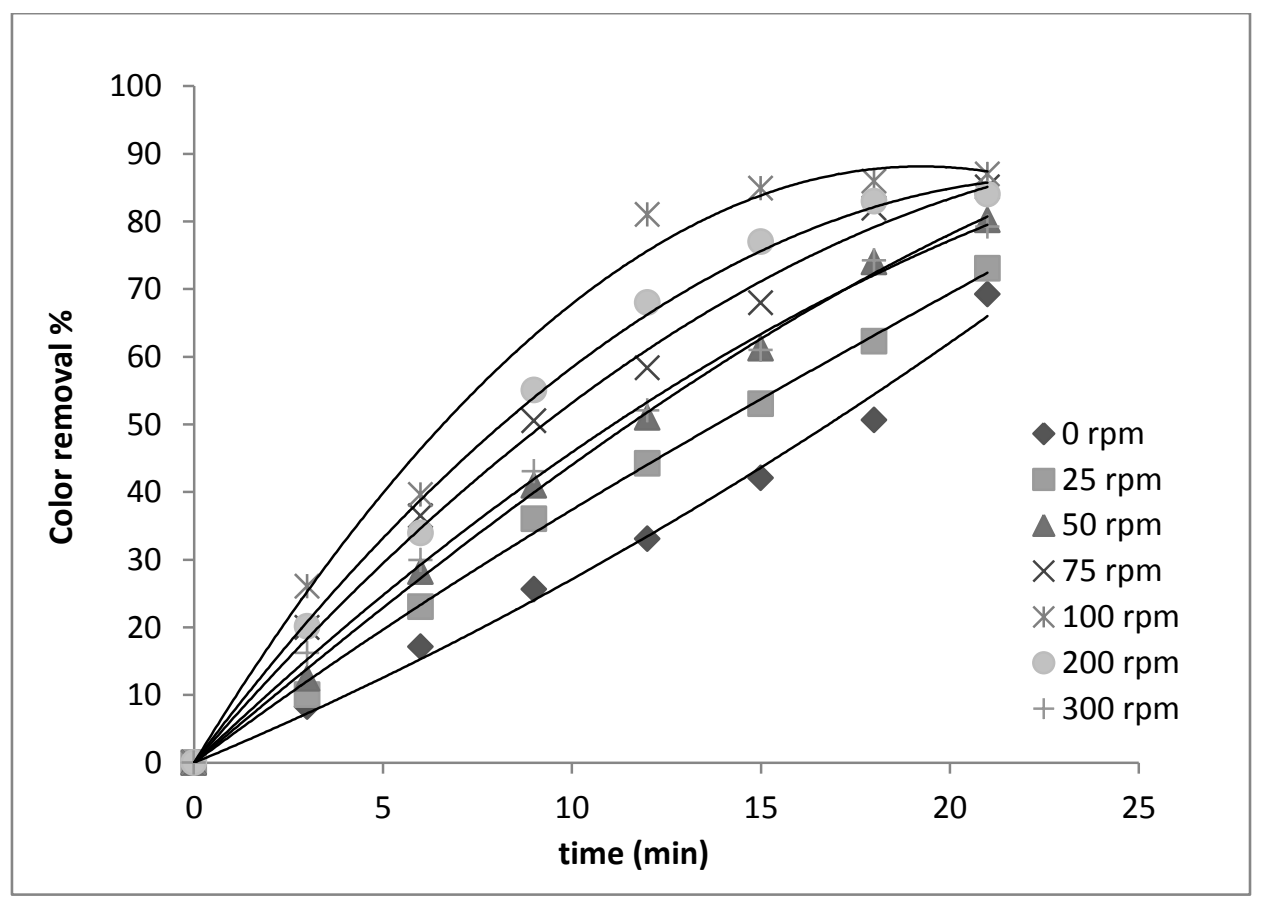

Fig.2, Color removal percentage vs. time at different agitation rotational speed, using screen cathode [C.D= $\left.200 \mathrm{~A} / \mathrm{m}^{2}, \mathrm{C}_{\mathrm{NaCl}}=5 \mathrm{~g} / \mathrm{l}, \mathrm{C}_{0}=50 \mathrm{ppm}\right]$ 


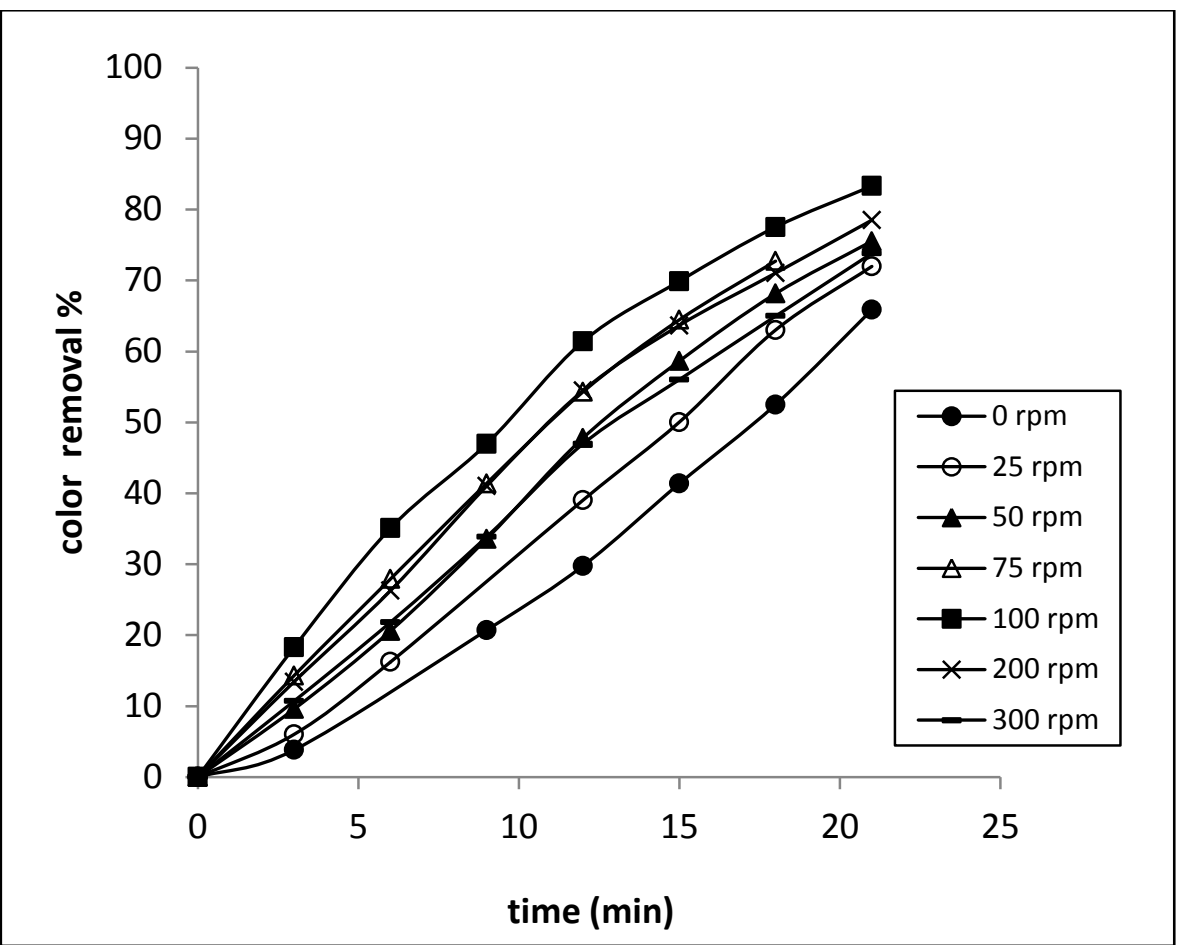

Fig.3: Color removal percentage vs. time at different rotational speed using sheet cathode $\left[C . D=200 \mathrm{~A} / \mathrm{m}^{2}\right.$, $\left.\mathrm{C}_{\mathrm{NaCl}}=5 \mathrm{~g} / \mathrm{l}, \mathrm{C}_{0}=50 \mathrm{ppm}\right]$

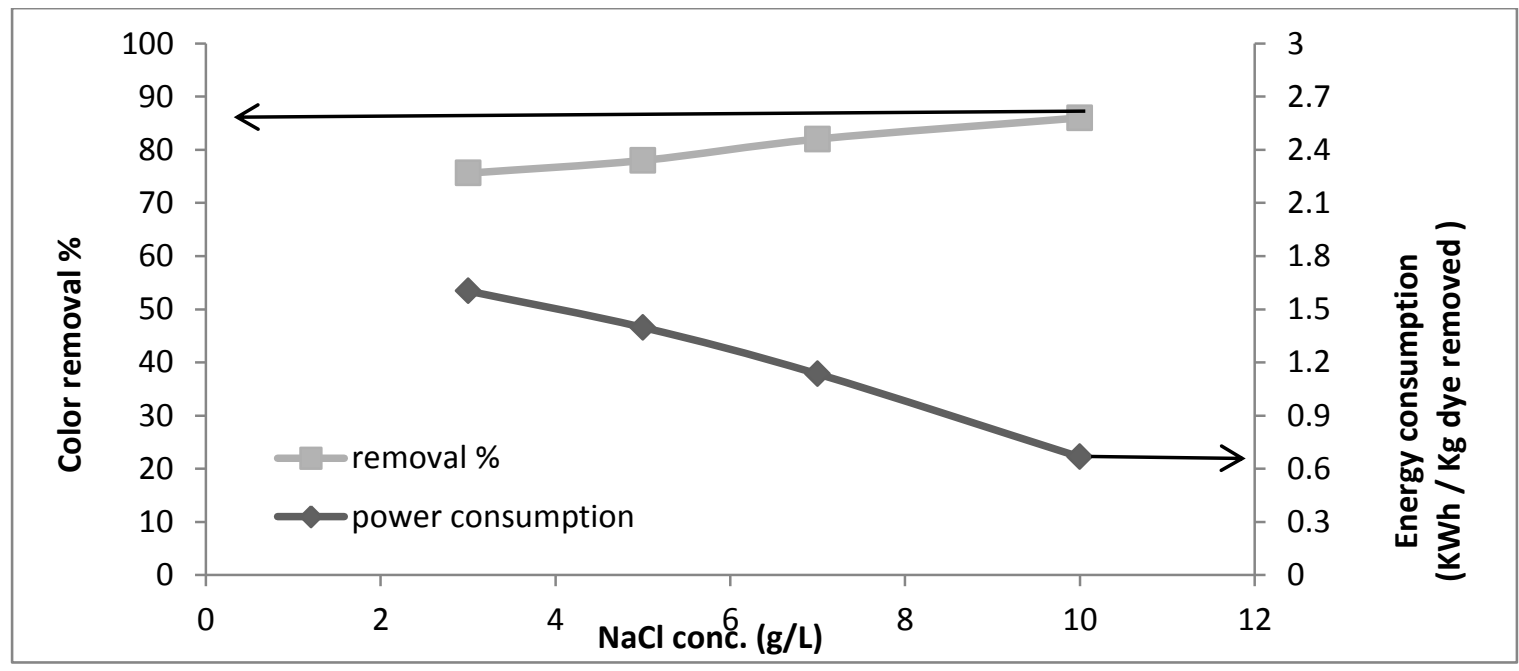

Fig. 4: Effect of initial $\mathrm{NaCl}$ concentration on the color removal efficiency and energy consumption, using screen cathode, $\left[\mathrm{C}_{0}=250 \mathrm{ppm}, \mathrm{C} . \mathrm{D}=125 \mathrm{~A} / \mathrm{m}^{2}\right.$, rotational speed $=100 \mathrm{rpm}$, time $\left.=21 \mathrm{~min}\right]$ 
Vol. 39, No. 1. January 2020

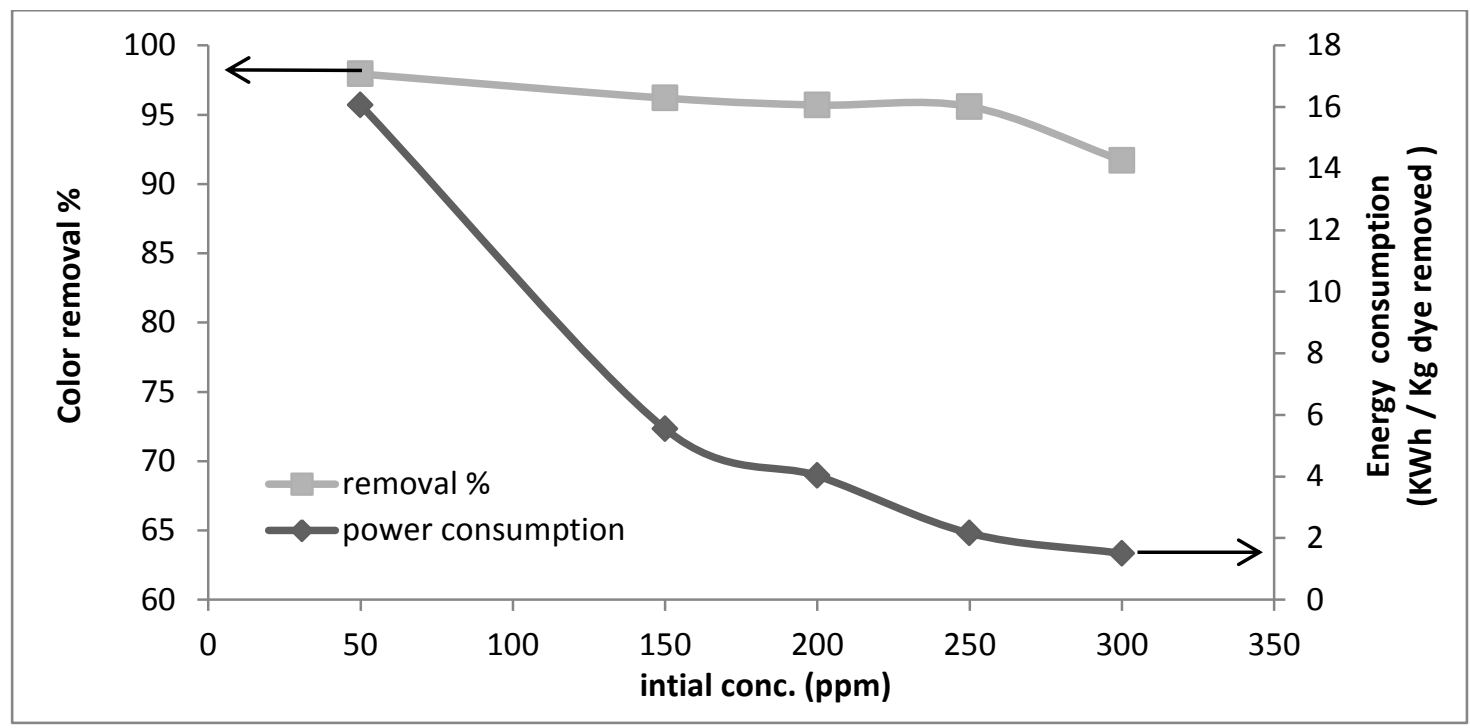

Fig. 5: Effect of initial conc. on the color removal efficiency and energy consumption, using vertical cylindrical screen cathode $\left[\mathrm{C} . \mathrm{D}=250 \mathrm{~A} / \mathrm{m}^{2}\right.$, rotational speed $=100 \mathrm{rpm}, \mathrm{C}_{\mathrm{NaCl}}=10 \mathrm{~g} / \mathrm{l}$, time $\left.=21 \mathrm{~min}\right]$

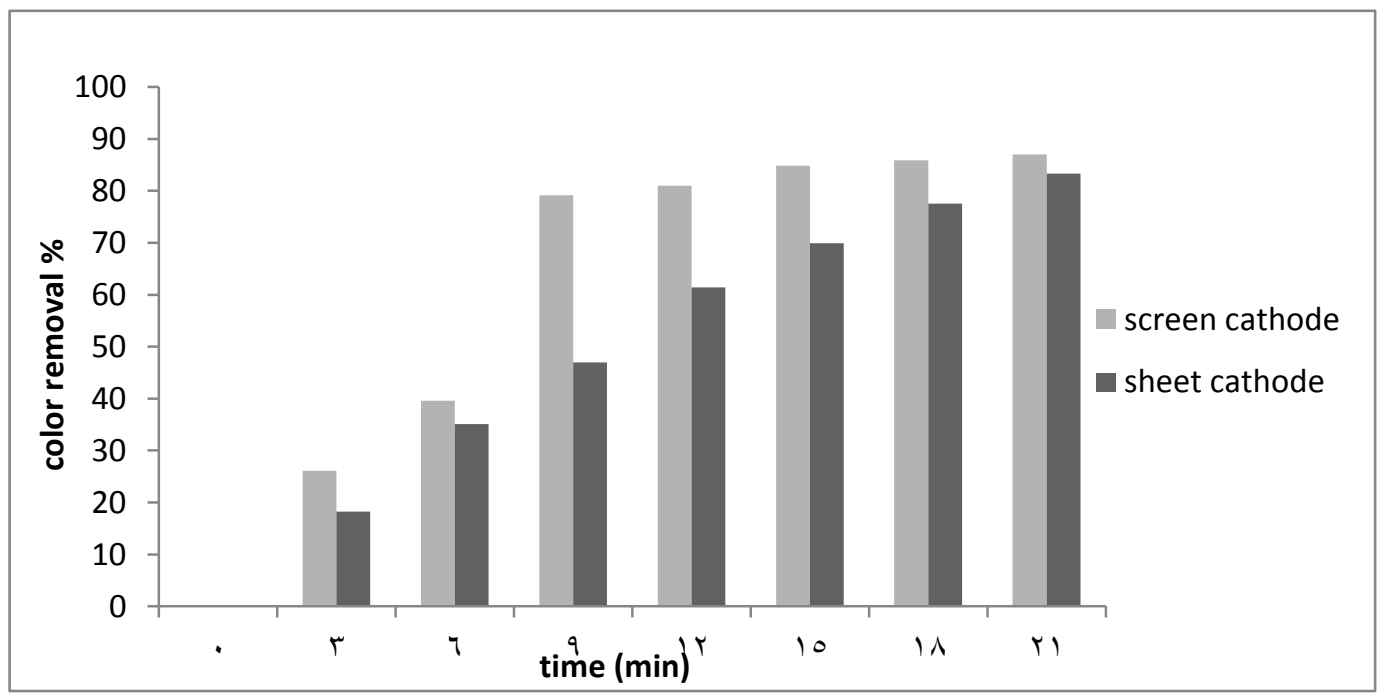

Fig. 6: Color removal percentage vs. time $(\mathrm{min})$ using screen and vertical cylindrical sheet cathodes respectively $\left[\mathrm{C} . \mathrm{D}=200 \mathrm{~A} / \mathrm{m}^{2}\right.$, rotational speed $\left.=100 \mathrm{rpm}, \mathrm{C}_{\mathrm{NaCl}}=5 \mathrm{~g} / \mathrm{l}, \mathrm{C}_{0}=50 \mathrm{ppm}\right]$ 